\title{
The internal structure of rock glaciers and recently deglaciated slopes as revealed by geoelectrical tomography: insights on permafrost and recent glacial evolution in the Central and Western Alps (Italy-France)
}

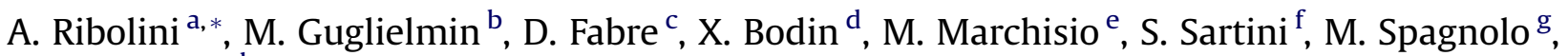 \\ P. Schoeneich ${ }^{\mathrm{h}}$ \\ a Dipartimento di Scienze della Terra, Università di Pisa, Pisa, Italy \\ ${ }^{\mathrm{b}}$ Dipartimento di Biologia Strutturale e Funzionale, Università dell'Insubria, Varese, Italy \\ ${ }^{\mathrm{c}}$ Conservatoire National des Arts et Métiers, Paris, France \\ ${ }^{\mathrm{d}}$ University of Waterloo, Waterloo, Ontario, Canada \\ e Dipartimento di Ingegneria Civile, Università di Pisa, Pisa, Italy \\ ${ }^{\mathrm{f}}$ SO.GE.T., Società di Geofisica, Lucca, Italy \\ ${ }^{\mathrm{g}}$ Department of Geography, University of Sheffield, Sheffield, United Kingdom \\ ${ }^{\mathrm{h}}$ Institut de Géographie Alpine, Grenoble, France
}

\section{A R T I C L E I N F O}

\section{Article history:}

Received 19 May 2009

Received in revised form

14 October 2009

Accepted 15 October 2009

\begin{abstract}
A B S T R A C T
Ground ice of permafrost origin and sedimentary ice of glacial origin can coexist in locations where rock glaciers and glaciers interacted, as well as in glacigenic sediments abandoned by a retreating glacier and subsequently exposed again to atmospheric cooling. Some of these geomorphological settings in the Central (Foscagno rock glacier) and Western Alps (Marinet and Schiantala rock glaciers, Schiantala debris-covered glacier, Maledia glacier) were explored by means of geoelectrical tomographies. The aim was that of inferring the presence of ice and cryologically interpreting electrical stratigraphies in order to test whether or not the internal structure of these landforms can be used for the reconstruction of recent permafrost and glacier evolution. Geomorphological data assisted these reconstructions and available borehole stratigraphies were used to calibrate the resistivities.

Along with the ice-debris mixture, massive ice has also been found as lenses both at the apex and the front of the studied rock glaciers. These lenses of sedimentary origin are thought to be transferred from a glacier snout to sectors of rock glacier and eventually embedded into the permafrost creep. The scarcity of frozen debris in the mid-upper part of the rock glaciers - as revealed by low resistivity values - can be due to the disruptive effect of the over-riding glacier over the permafrost.

The near-surface sedimentary ice masses detected along the slopes of the studied glacial cirques are interpreted as or debris-covered terminations of the glaciers still visible upward, or as fragments of it detached by the main bodies. These ice masses are locally associated to medium-high resistive sediments, consistent with permafrost occurrence. This indicates that the non-glacial environment established during the deglaciation allowed the onset of frozen sediments formation.

Overall, the results indicate that internal structure of rock glaciers and recent-deglaciated slopes can store the different climate-related episodes occurred in a specific area, such as those linked to the shifting between glacial to criotic condition and vice-versa.
\end{abstract}

(C) 2009 Elsevier Ltd. All rights reserved.

\section{Introduction}

The relationships between rock glaciers and glaciers represent one of the biggest issues in the geomorphology of cold

\footnotetext{
* Corresponding author. Tel.: +39 502215845; fax: +39 502215800.

E-mail address: ribolini@dst.unipi.it (A. Ribolini).
}

mountains because both landforms respond to changes in thermal boundary conditions that are largely climatically controlled, although in different ways (Etzelmüller and Hagen, 2005; Haeberli, 2005).

In rock glacier cores both recongelation ice layers (i.e. ground ice) and sedimentary ice bodies (i.e. glacial origin) can be found (Clark et al., 1996; Guglielmin et al., 2004; Stenni et al., 2007). Changes in ice content within a rock glacier can be due to a partial 
interaction and overlapping with a glacier (Etzelmüller and Hagen, 2005; Haeberli, 2005; Harris and Murton, 2005).

On the other hand, glacier forefields newly exposed to atmospheric cooling after a glacial retreat can be affected by permafrost aggradation, and in these areas new ground ice masses can form and coexist with bodies of relict buried sedimentary ice (Kneisel, 2003; Etzelmüller and Hagen, 2005; Kneisel and Kääb, 2007).

For this reason, exploring distribution and nature of subsurface ice in rock glaciers, recently deglaciated slopes and sectors where glaciers and rock glaciers interacted assumes a crucial importance to understand the recent permafrost and glaciers evolution (Moorman and Michel, 2000; Everest and Bradwell, 2003; Kneisel, 2003; Reynard et al., 2003; Kneisel, 2004; Kääb and Kneisel, 2006; Kneisel and Kääb, 2007). In these geomorphological settings, the analysis of ice cores allows to define the nature of buried ice. However, soundings are expensive and difficult to realize in the alpine environment, and it is not surprise that there are only a few cases in the world (see in Haeberli et al., 2006; Stenni et al., 2007). Geophysical prospection integrated with a geomorphological survey proved to be a useful tool to detect shape and physical properties of ice bodies/layers internal to rock glaciers and glacigenic sediments, and to correctly interpret how they formed and evolved (Reynard et al., 2003; Berger et al., 2004; Lugon et al., 2004; Ribolini et al., 2007).

Among the several geophysical methods employed, DC geoelectrical resistivity is one of the most reliable because of the much higher resistivity of ice and permafrost layers in respect to unfrozen sediments and bedrock (Hauck, 2001; Maurer and Hauck, 2007 and references therein). In the last years, multielectrodes DC resistivity investigation associated with techniques of geophysical data imaging (tomography) has strongly improved the subsurface ice detection, enabling detailed 2D reconstructions of massive ice lens or ice-bearing layers (Hauck et al. 2003; Kneisel, 2004 and reference therein).

In this work we present the results of DC resistivity tomography investigations undertaken in 1 site in the Central Alps (Italy) and 3 sites in the SW Alps (Maritime and Cothian Alps, France-Italy), covering a total latitudinal shift of more than $2^{\circ}$ (Fig. 1 ). These sites were selected because they represent different geomorphological contexts (rock glaciers, debris-covered glaciers, and recently deglaciated slopes) and different climatic setting. While in the Maritime Alps permafrost is near to its climatic limit for existence (Ribolini, 2001; Ribolini and Fabre, 2006), in the Central Alps permafrost preservation/aggradation is more favorable (Guglielmin et al., 1994). With this work we intend to explore the internal structure of these landforms and, assisted by geomorphological reconstructions, to retrieve information useful to the understanding of the recent permafrost and glaciers evolution and mutual relationships.

\section{Study areas and general climatic settings}

From North to South the studied areas are: the Foscagno rock glacier in the Italian Central Alps $\left(46^{\circ} 29^{\prime} \mathrm{N}, 10^{\circ} 11^{\prime} \mathrm{E}\right)$; the Marinet rock glacier in the French Cothian Alps $\left(44^{\circ} 33^{\prime} \mathrm{N}, 6^{\circ} 51^{\prime} \mathrm{E}\right)$; the Schiantala rock glacier in the Italian Marittime Alps $\left(44^{\circ} 17^{\prime} \mathrm{N}\right.$, $7^{\circ} 00^{\prime} \mathrm{E}$ ) and the Maledia glacier area in the Italian Marittime Alps $\left(44^{\circ} 07^{\prime} \mathrm{N} ; 7^{\circ} 24^{\prime} \mathrm{E}\right)$ (Fig. 1 ).

The Foscagno valley is characterized by a mean annual air temperature ranging between $1.5^{\circ} \mathrm{C}$ at $2400 \mathrm{~m}$ a.s.l. and $-1{ }^{\circ} \mathrm{C}$ at $2800 \mathrm{~m}$ a.s.l., with a total precipitation around $850 \mathrm{~mm}$.

In the area of Marinet and Schiantala rock glaciers the mean annual air temperature is $2.5^{\circ} \mathrm{C}$ at about $2300 \mathrm{~m}$ a.s.l. The snow cover is generally thin, exceeding $50 \mathrm{~cm}$ in the November-April with a maximum generally in April $(>100 \mathrm{~cm})$.
In the Maledia glacier area the mean annual air temperature at $2000 \mathrm{~m}$ a.s.l. is $3.8^{\circ} \mathrm{C}$. Snow cover generally develops at the beginning of October, reaching a maximum thickness of $>80 \mathrm{~cm}$ in January.

\subsection{Foscagno rock glacier}

The Foscagno rock glacier develops in the Foscagno Valley, which is a tributary of the Viola Bormina Valley in the upper Valtellina (Central Alps). The valley is dominated by the Mt Forcellina cirque (Fig. 2a), occupied by a small glacier until AD 1932. This glacier extended down to 2650 a.s.l. during the Little Ice Age (LIA) maximum extent (Guglielmin et al., 2001). The present-day rock glacier extends for about $800 \mathrm{~m}$, assuming a complex landform with several lobes characterized by prominent concentric ridges (Fig. 2b). The limit between the active and inactive parts is represented by a steep and bilobate-shaped ridge crossing the rock glacier at about 2450-2500 m a.s.l. Radiocarbon dates of paleosoils buried by the NW lobe of the active part and by the frontal lobe of the inactive part show uncalibrated ages of $2200 \pm 60 \mathrm{yr} \mathrm{BP}$ and $2700 \pm 70 \mathrm{yr}$ BP respectively (Calderoni et al., 1998). Permafrost is patchily distributed within the rock glacier and its thickness is variable between $8 \mathrm{~m}$ and more than $50 \mathrm{~m}$ while the active layer ranges from 1.5 to $10 \mathrm{~m}$ as resulted by several geophysical investigations undertaken in various part of the rock glacier (Guglielmin et al., 1994; Guglielmin, 1997; Hauck, 2001). Two boreholes $\left(\mathrm{S}_{0}, \mathrm{~S}_{3}\right)$ were drilled on the rock glacier (Fig. $2 b$ ), and one $\left(S_{2}\right)$ immediately outside its uppermost side in the area occupied by the Foscagno glacier until AD 1932. The $S_{0}$ borehole (2500 m a.s.l.) is $24 \mathrm{~m}$ deep and the core showed massive sedimentary ice between 2 and $7 \mathrm{~m}$ depth, resting onto ice-rich sediments extended up to $17 \mathrm{~m}$ depth where unfrozen debris starts. Bedrock was reached at $23.50 \mathrm{~m}$ depth (Guglielmin et al., 2001, 2004). The sedimentary ice detected in $S_{0}$ was interpreted as a relict of the Holocenic glacier tongue (Guglielmin et al., 2004) that during the Mediaeval Warm Period (calibrated calendar age ranging between AD 765 and 1260) was present in the area and that has been preserved within the rock glacier up to now without appreciable freezing and thawing phenomena (Stenni et al., 2007).

\subsection{Marinet rock glacier}

The Marinet rock glacier is located on the northern side of the Aiguille de Chamberyron, in the Haute Ubaye valley (France) (Fig. 3a). The rock glacier develops for about $700 \mathrm{~m}$ starting from the downstream end of a small corrie glacier (Marinet Glacier West) and spreading out onto the valley floor where it borders the Marinet lake (Fig. 3b). Advances of rock glacier front deformed the lake sediments on the shoreline creating an evident bulge. Evin and de Beaulieu (1985) analyzed the pollen content of these deformed sediments and proposed a Lateglacial age for the onset of the rock glacier formation. In 1924, the Marinet Glacier was still occupying the area now covered by the root of the rock glacier (Mougin, 1927), but during the LIA it extended well below, approximately in the area of the present mid-upper part of the rock glacier (Evin and de Beaulieu, 1985; Whalley and Palmer, 1998; Assier, 1996).

\subsection{Schiantala rock glacier and glacier}

The Schiantala rock glacier lies in the uppermost part of the Piz Valley (Argentera Massif, Maritime Alps), on the southern flank of the Mt. Testa dell'Ubac (Fig. 4). The rock glacier develops from glacigenic sediments (frontal moraine) covering the downvalley margin of the cirque floor, and extends for about $600 \mathrm{~m}$ terminating with a steep front at $2450 \mathrm{~m}$ (Fig. 4). 


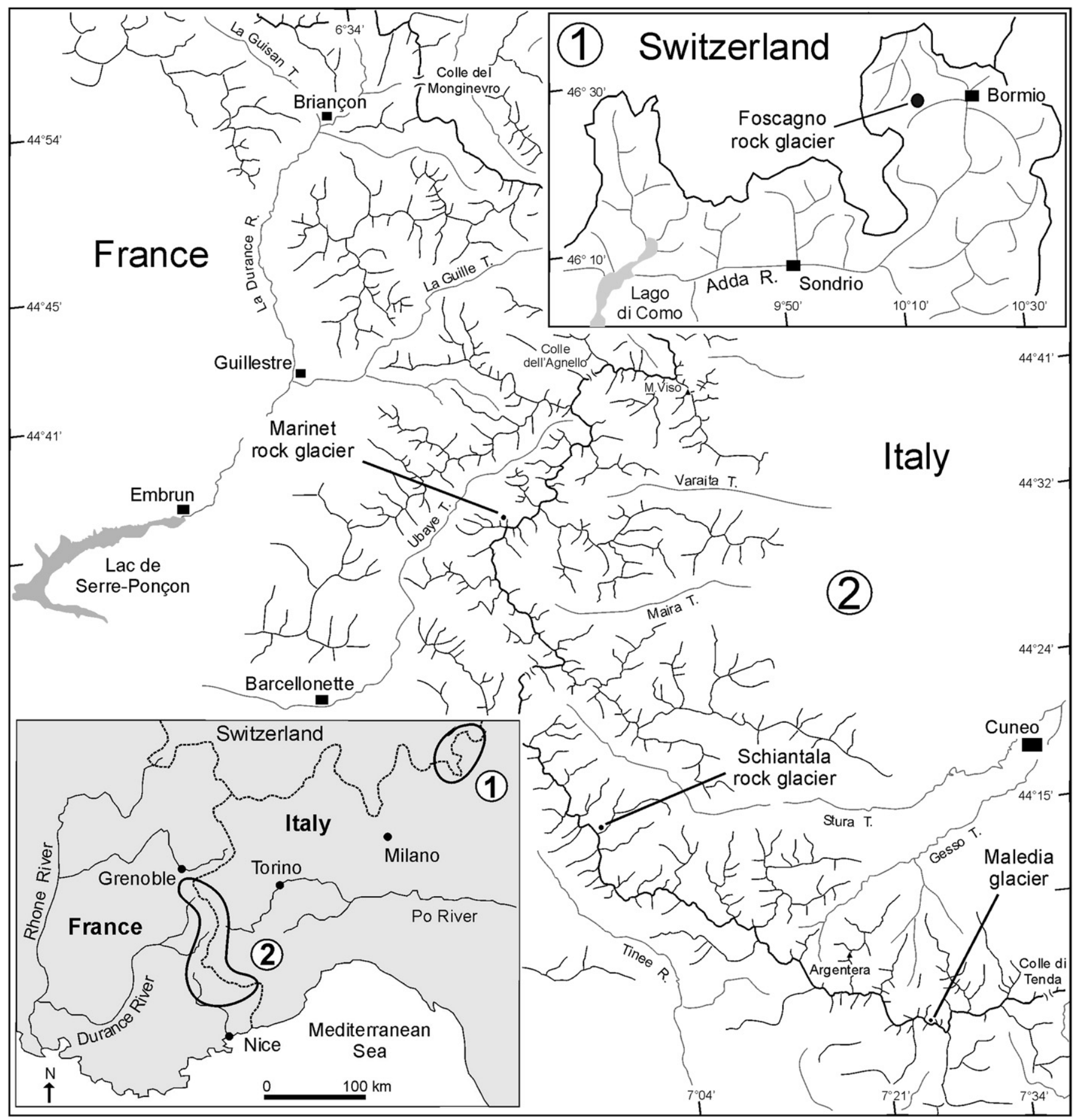

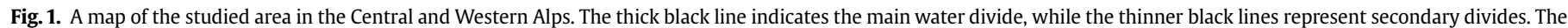
grey lines refer to the main rivers draining the areas.

The Schiantala glacier, covered by a few decimeters of glacigenic debris, can still be found on the cirque floor upvalley from the rock glacier (Camoletto, 1931; Ribolini et al., 2007). A depression, partly occupied by a lake, exposes a cross section of the debris and the underlying glacier, this latter clearly characterized by massive ice foliations. At the beginning of the 20th century, the depression was not formed yet and massive ice was only visible inside a crevasse opened in the detritical surface (Camoletto, 1931). This led the operators of the Italian Glaciological Committee to first suggest the presence of a Schiantala Glacier, although totally covered by debris (i.e. debris-covered glacier). Conversely, Evin (1993) stated that this massive ice corresponds to ice-rich permafrost, as frequently found at the top of rock glaciers. In Evin interpretation, the melting of this permafrost induced the formation of a typical thermokarst lake. Ribolini et al. (2007) demonstrated that the massive ice outcropping along the lake bank is sedimentary in origin, and proposed that it represents what remains of the Schiantala glacier now completely covered in debris. 


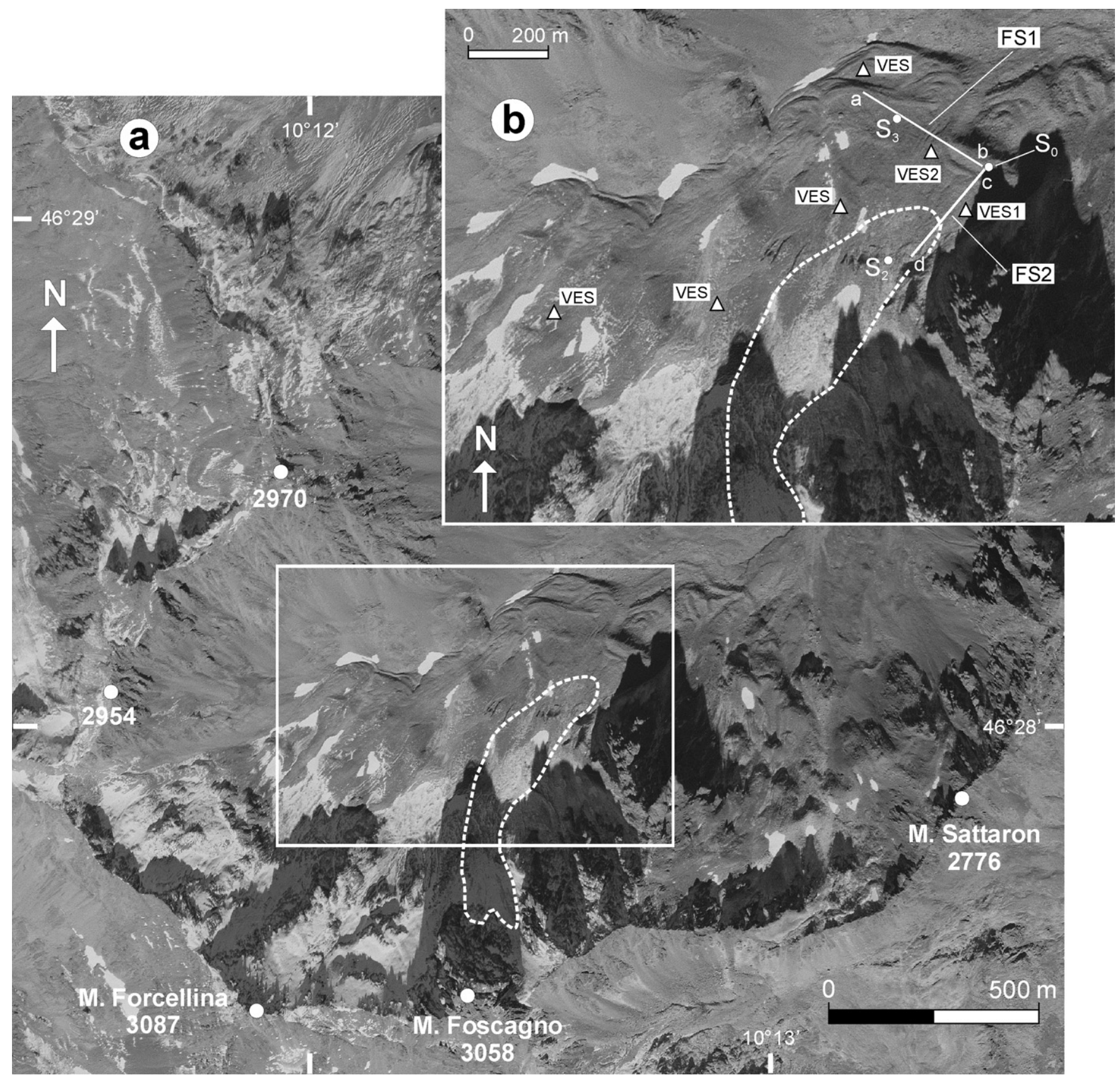

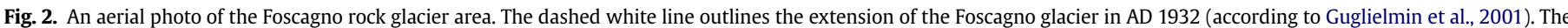
location of the tomography profiles (FS1 and FS2), boreholes $\left(\mathrm{S}_{0}, \mathrm{~S}_{2}, \mathrm{~S}_{3}\right)$ and the previous Vertical Electric Sounding (VES) is shown in the subset picture.

\subsection{Maledia glacier}

The Maledia glacier is one of the southernmost glaciers of the Alpine chain and as such it has experienced an intense process of contraction in the past decades (Federici and Pappalardo, 1995; Pappalardo, 1999). Some other glaciers from nearby, known to have existed in the recent past, have now totally disappeared, while others have undergone to a progressive debris covering of the surface (Fig. 5). The Maledia glacier expanded during the LIA until a maximum extension of $0.15 \mathrm{~km}^{2}$. In the early 1900 it was partly debris covered but still in movement, as testified by the crevasses visible in old photographs. Since then, it experienced an extensive reduction, becoming more and more covered by debris fed by freeze/thaw processes and rock falls from the cirque walls. In the early 1990s, the presence of moving ice in the cirque floor was ensured and a glacial-karst lake was well visible in the forefield (Federici and Pappalardo, 1995). Today, the presence of moving ice is improbable and the true extension of the glacier is undetectable through ordinary glaciological field survey because of the widespread debris coverage. The sedimentary ice is clearly visible only tight to the base of the cirque wall (Fig. 5).

\section{Method}

The 2D geoelectrical tomography survey started with the field procedure of the so called "resistivity pseudo-section" (Telford et al., 1990). A series of 48 electrodes were fixed into the ground along a linear profile spaced $2 \mathrm{~m}$ apart. Ground-electrode contacts 


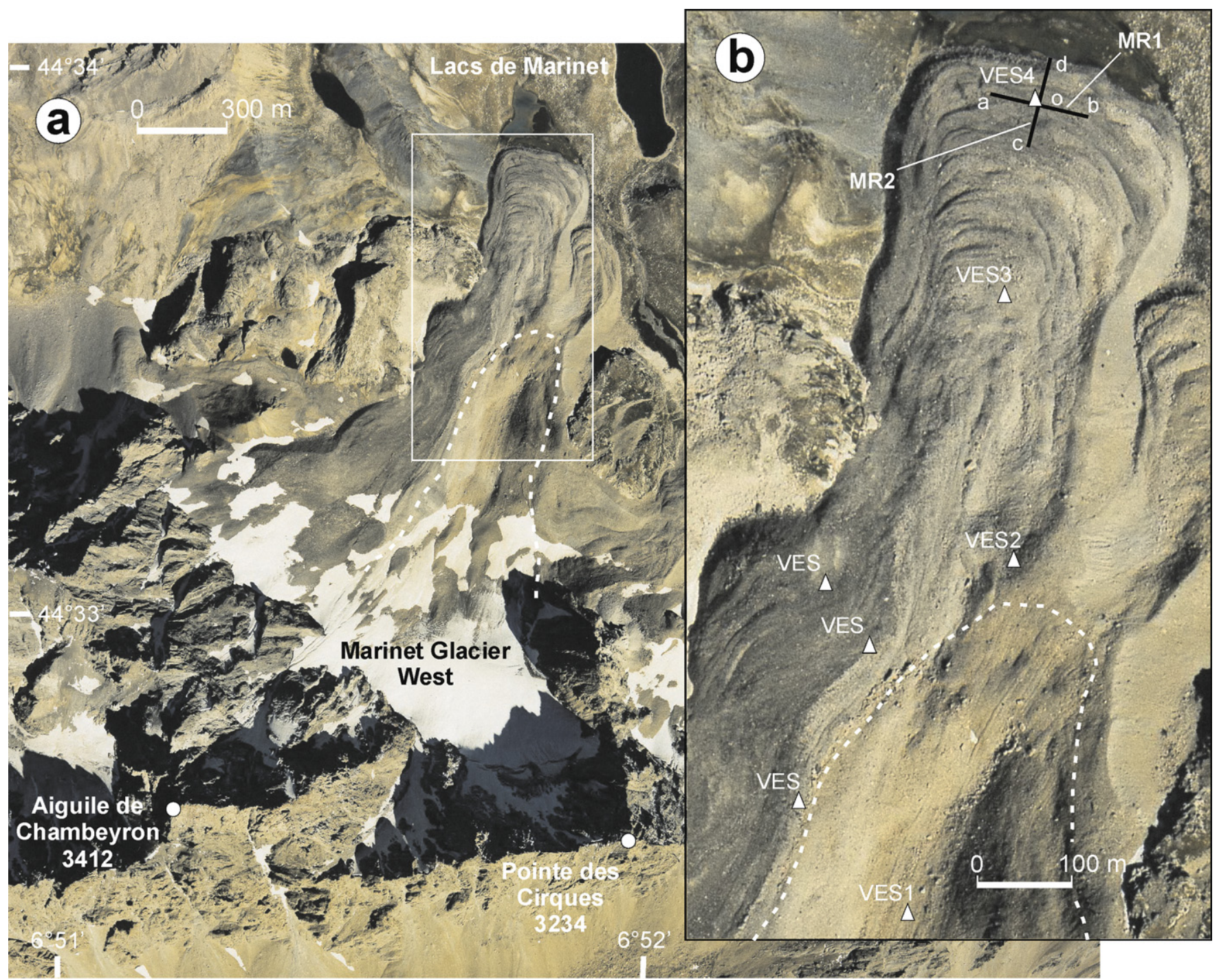

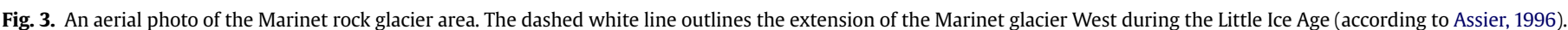

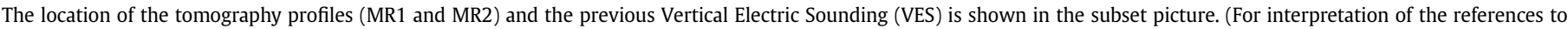
colour in this figure legend, the reader is referred to the web version of this article.)

were improved adding salted water. The electrodes were connected to a SYSCAL R1 Georesistivity Meter (10 M $\Omega$ input impedance) by means of multi-polar cables. The instrument was programmed to perform a series of resistivity measurements connecting four electrodes per time (two electrodes injecting current into the ground and two electrodes measuring the potential difference) according to pre-fixed sequences. The measurements are made using several classical 4-electrode spread: Wenner, Dipole-Dipole, Pole-Dipole. In detail, the Dipole-Dipole array configuration was chosen for its penetration depth and good resolution for lateral heterogeneities, and the Wenner for its stability and low sensitivity. In order to undertake long profiles, a roll-along acquisition technique was used.

An apparent resistivity pseudosection was acquired for each profile by means of a mathematical combination between electric currents and voltage measurements. To obtain a true geoelectrical tomography in a vertical section under the profile, 2D inversions of resistivity were performed using the TomoLab software developed by Geostudi Astier srl (www.geoastier.it) that adopts a Finite Elements (FEM) 2D forward modelling algorithm. The earth-domain is discretized using quadrilateral elements. A conjugate gradient solver is used, with preconditioning based on the incomplete Cholesky solver. The inversion procedure is based on a least squares smoothness constrained approach (LaBrecque et al., 1996). Noise is appropriately managed using a data weighting algorithm (Morelli and LaBrecque, 1996) that allows to adaptively change the variance matrix after each iteration for those data points which are poorly fit by the model. $\mathrm{Chi}^{2}$ statistic was used to test how well measured values fit theoretical model (Davis, 1990).

Surface topography, measured in the field using graduated stacks, was incorporated in the data inversion. This operation is necessary when topography is strongly rugged because current flow tends to concentrate into surface depressions (trench) and disperse or diverge on ridge crests, generating distortion in the results (Telford et al., 1990).

The cryological interpretation of the resistivities is also very delicate and here we used the resistivity values intervals classification proposed by Haeberli and Vonder Mühll (1996). For the Foscagno rock glacier the resistivity intervals were calibrated using the stratigraphies of the available boreholes along the tomography arrays. 


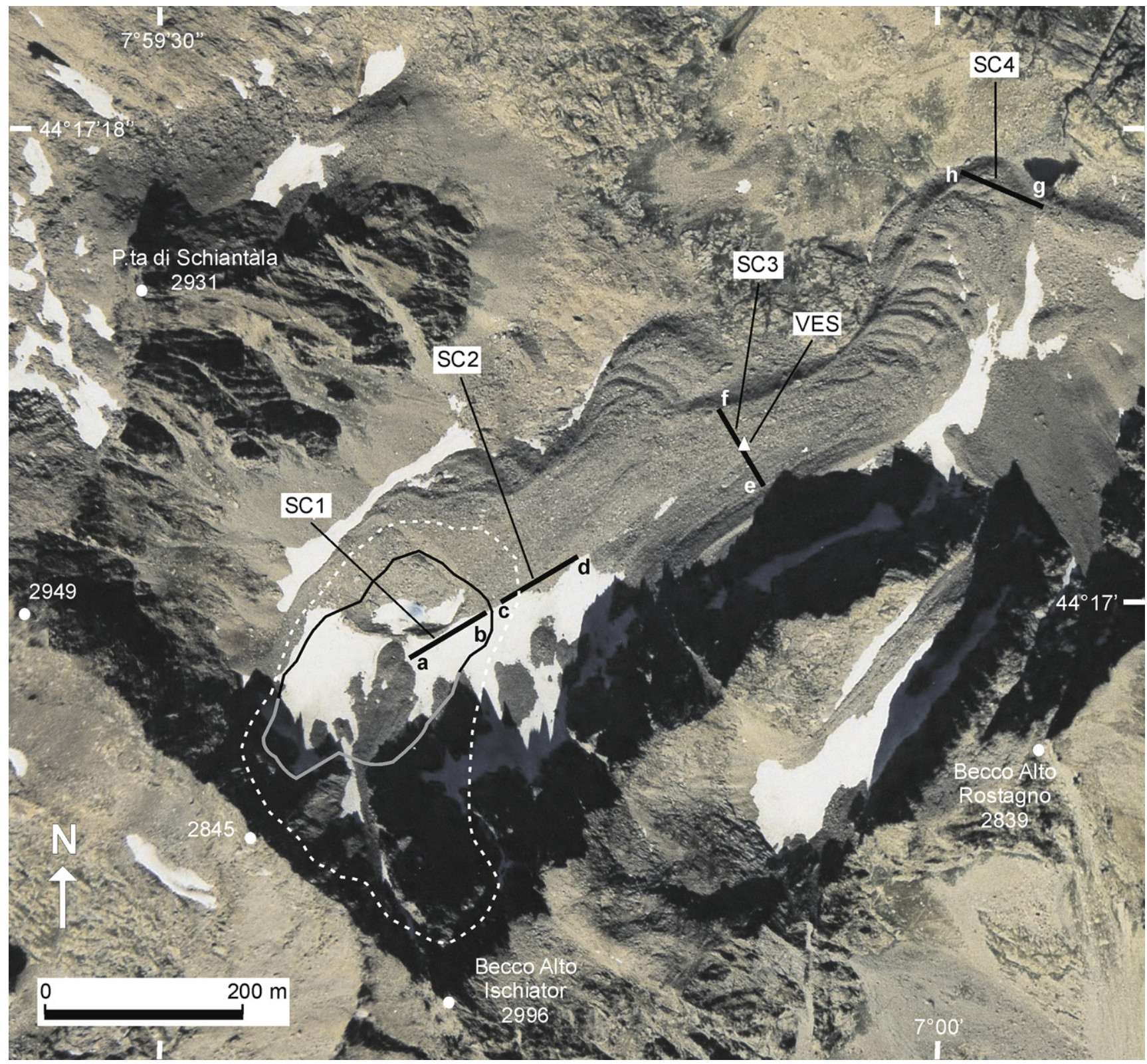

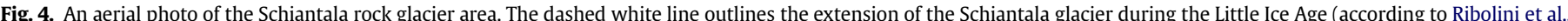

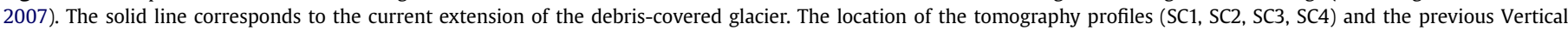
Electric Sounding (VES) is also shown. (For interpretation of the references to colour in this figure legend, the reader is referred to the web version of this article.)

\section{Results}

\subsection{Foscagno rock glacier}

Adopting the techniques of the roll-along, two long geoelectrical tomographies were undertaken. The first was carried out in the frontal part of the active rock glacier transversally to the flow direction (FS1), while the second was settled parallel to the flow direction on a lobe in the SE part of the active rock glacier (FS2). The tomographies intercept the two boreholes $\left(\mathrm{S}_{0}, \mathrm{~S}_{3}\right)$ (Fig. $2 \mathrm{~b}$ ).

The surface layer shows relatively low resistivity values $(<40 \mathrm{k} \Omega \mathrm{m})$ and it is generally very thin $(1-2.5 \mathrm{~m})$ except for the central and lateral parts of the FS1 where it can exceed $5 \mathrm{~m}$ (Fig. 6a). Beneath this surface layer, in the centre-NW part of FS1 there is a large body of high resistivity ( $>1 \mathrm{M} \Omega \mathrm{m}$ ) that exceeds $20 \mathrm{~m}$ of thickness (in correspondence of the borehole $S_{3}$ ). Other two thinner
(5-10 m) lenticular shaped masses of high resistivity occur centreSE of FS1 (Fig. 6a). All these bodies are surrounded by resistivity greater than $90-100 \mathrm{k} \Omega \mathrm{m}$.

The lowermost NE side of FS2 is dominated by a high resistive layer (1-8 M $\Omega \mathrm{m}$ ), constantly thicker than 10-13 m (Fig. 6b). The resistivity of this layer progressively diminishes rising the slope, becoming fragmented in two minor lenses $(>900 \mathrm{k} \Omega \mathrm{m})$ embedded in more conductive sediments $(\sim 100 \mathrm{k} \Omega \mathrm{m})$. At $2648 \mathrm{~m}$ a.s.l., the resistivities of the tomography drastically change, assuming values constantly lower than $10 \mathrm{k} \Omega \mathrm{m}$, below 2-4 m of surface layer (Fig. $6 \mathrm{~b}$ ).

\subsection{Marinet rock glacier}

The lower part of the active rock glacier was investigated with a transversal profile (MA1) and a cross profile (MA2), intersecting in the middle point (Fig. 3b). 


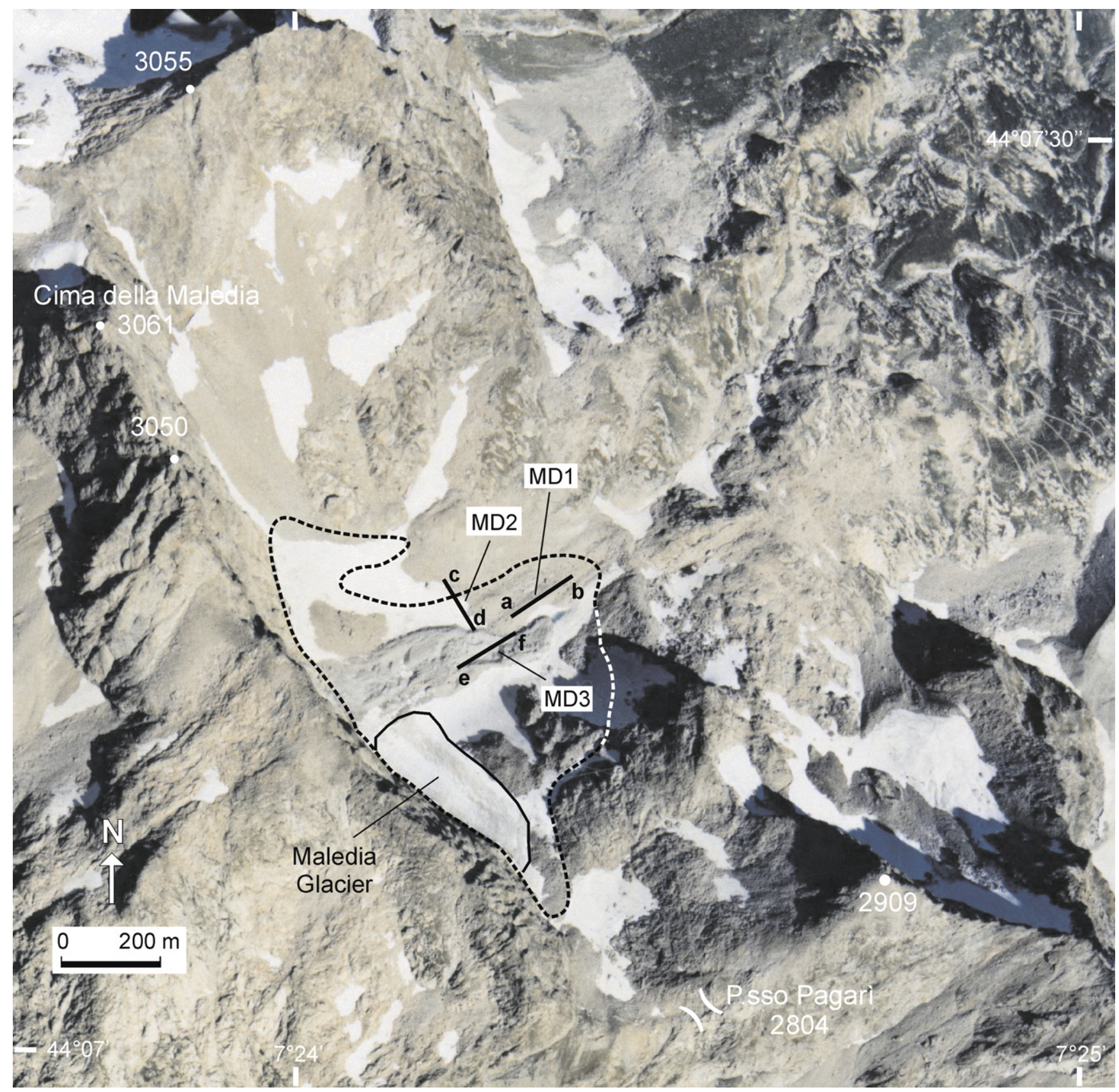

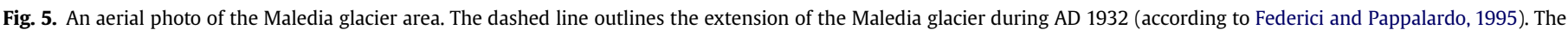

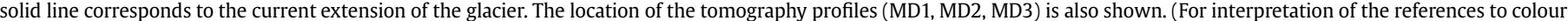
in this figure legend, the reader is referred to the web version of this article.)

The surface layer in MA1 presents resistivities ranging between 10 and $30 \mathrm{k} \Omega \mathrm{m}$ in the upper $3 \mathrm{~m}$, increasing with depth up to $50-70 \mathrm{k} \Omega \mathrm{m}$ (Fig. 7a). The depth of this surface layer is more irregular moving toward the NE margin of the rock glacier. A sharp contact with a body characterized by very high resistivity values $(>4-6 \mathrm{M} \Omega \mathrm{m}$ ) occurs at a depth of 6-8 $\mathrm{m}$ on the southwestern and central parts of the rock glacier, while in the northeastern side the resistivity is clearly lower $(<200 \mathrm{k} \Omega \mathrm{m})$.

The longitudinal profile (Fig. 7b) shows the limit between the surficial layer and the high resistivity body placed between 5 and $6 \mathrm{~m}$ of depth with a more irregular shape respect to the MA1, and also a deeper layer with values lower than $200 \mathrm{k} \Omega \mathrm{m}$ underlying the high resistivity mass.

In both tomographies, the thickness of the first upper layer does not increase in correspondence of the highest resistive masses.

\subsection{Schiantala glacier and rock glacier}

The tomographies were carried out on the cirque floor - where massive ice outcrops (SC1) - and in correspondence of the upper, central and lower parts of the rock glacier (SC2, SC3, SC4) (Fig. 4).

A sub-horizontal structure is shown by SC1 (Fig. 8a) with a very thin surficial layer $(50-70 \mathrm{k} \Omega \mathrm{m})$ discontinuously covering a highly resistive layer (100-600 $\mathrm{k} \Omega \mathrm{m})$. This latter, in turns, overlies a thick body characterized by values up to $6-8 \mathrm{M} \Omega \mathrm{m}$. The deepest layer gradually decreases its resistivity moving to $\mathrm{NE}$, approaching the border of the depression, where it is characterized by values lower than $3 \mathrm{M} \Omega \mathrm{m}$.

High resistivities characterize the upvalley part of SC2, at the rock glacier root (Fig. 8b) where a body of $600 \mathrm{k} \Omega \mathrm{m}$ occurs. Moving 
a
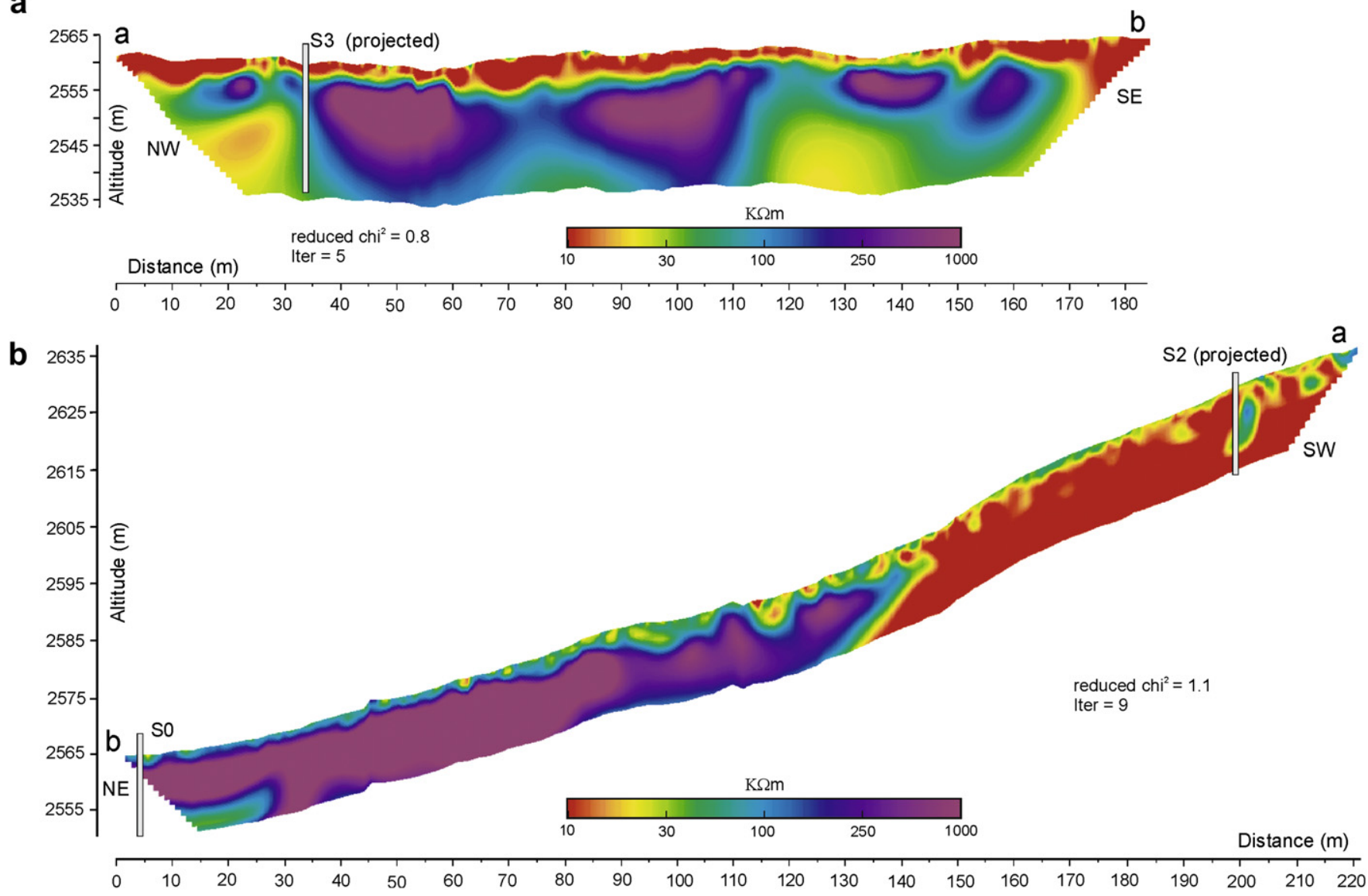

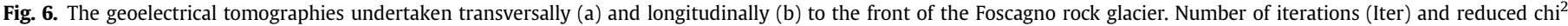

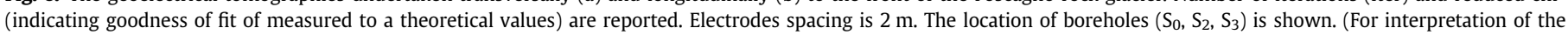
references to colour in this figure legend, the reader is referred to the web version of this article.)

downward, this body terminates sharply intruding a layer of relatively lower resistivity $(80-100 \mathrm{k} \Omega \mathrm{m})$.

The downvalley part of SC2 shows an upper layer (2-12 m depth) with resistivities of $10-20 \mathrm{k} \Omega \mathrm{m}$, locally interrupted by subcircular spots exceeding $30-40 \mathrm{k} \Omega \mathrm{m}$. Resistivity progressively increases with depth up to $12-15 \mathrm{~m}$, where it assumes values constantly higher than $40 \mathrm{k} \Omega \mathrm{m}$.

At the centre of the rock glacier, the distribution of SC3 and SC4 resistivity appears more irregular and with values generally lower than in the upper part (Fig. 8c). The surface layer (0-4 m) shows a high variability of resistivity in the $5-30 \mathrm{k} \Omega \mathrm{m}$ range. The $4-10 \mathrm{~m}$ interval is characterized by a wide layer with resistivities lower than $15 \mathrm{k} \Omega \mathrm{m}$. This layer is locally interrupted by sub-circular spots up to 1 order of magnitude more resistive $(200-300 \mathrm{k} \Omega \mathrm{m})$. A $30-50 \mathrm{k} \Omega \mathrm{m}$ value characterizes the lower layer.

The structure at the front of the rock glacier (Fig. 8d), below the very variable surficial layer $(0-3 \mathrm{~m})$, is characterized by the presence of 3 sub-circular zones of high resistivity $(100-150 \mathrm{k} \Omega \mathrm{m})$ inside a conductive layer $(20-30 \mathrm{k} \Omega \mathrm{m})$.

\subsection{Maledia glacier}

Three tomographies were undertaken at the cirque bottom of the Maledia glacier, both on glacial drift and slope debris (Fig. 5). The orientation of the profiles was chosen in order to cover part of the area occupied by the glacier at the beginning of 20th century (Federici and Pappalardo, 1995) Two tomographies on the NW slope were oriented respectively parallel (MD1) and about orthogonal (MD2) to the bank of the glacial-karst lake formed on the cirque floor in the 1990s. Tomography 3 (MD3) was oriented following the cirque axis starting from the southern limit of the lake (Fig. 5).

In the Maledia area, the grain size of the deposits is different than in the other investigated sites. Along with large blocks, a higher content of sandy gravel matrix is present and the deposit locally assumes a matrix-supported fabric.

MD1 (Fig. 9a) shows an upper layer (0-8 m) of resistivity higher than $10 \mathrm{k} \Omega \mathrm{m}$, locally presenting some lenticular lenses with a resistivity higher than $40 \mathrm{k} \Omega \mathrm{m}$ at depths variable within 1-3 m. These lenses follow the trend of the detritical surface, being concentrated in correspondence of the topographic culminations. The lowest layer $(>8 \mathrm{~m})$ presents a very low resistivity $(<5-7 \mathrm{k} \Omega \mathrm{m})$ and an undulated upper limit. The concave parts of this limit correspond to the topographic culminations on the surface.

MD2 shows a sharp difference between the SE side where a very resistive layer (6-8 $\mathrm{M} \Omega \mathrm{m}$ ) extends down to 5-7 $\mathrm{m}$ in respect to the opposite side where no resistive layer occurs. At greater depth $(>8 \mathrm{~m}$ ), a layer lower than $2 \mathrm{k} \Omega \mathrm{m}$ characterizes most of the tomography (Fig. 9b).

Analogously to MD2, the upper part of MD3 (SW side) shows a shallow highly resistive (1-5 M $2 \mathrm{~m}$ ) lens in the 2-6 $\mathrm{m}$ interval of depth, overlaying a 100-170 k $\Omega$ m layer (Fig. 9c). Moving to the NE side of the tomography, other spots of high resistivity were measured in the first $6-8 \mathrm{~m}$ of depth. They show a progressive decrease in the resistivity while moving toward lower portions of the slope. 
a 0

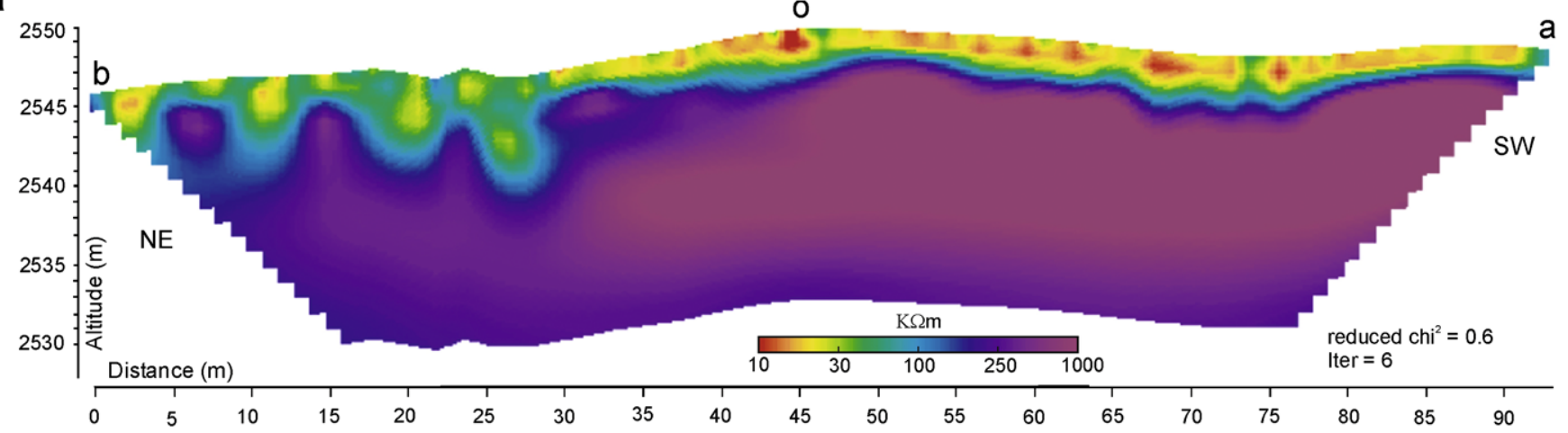

b

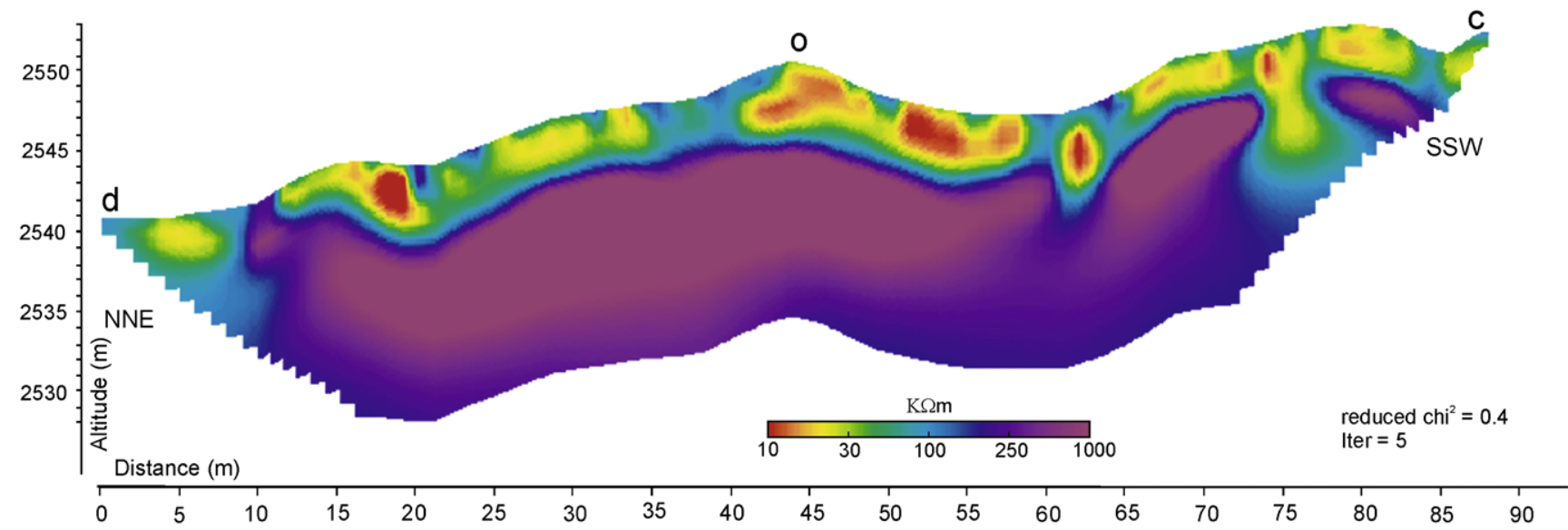

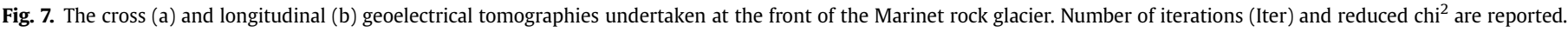
Electrodes spacing is $2 \mathrm{~m}$. (For interpretation of the references to colour in this figure legend, the reader is referred to the web version of this article.)

\section{Discussion}

\subsection{Nature of ice and geophysics}

The boreholes in the Foscagno rock glacier and the ice outcropping in the Schiantala area allow to associate the found resistivities to specific ice-debris mixing.

\subsubsection{Foscagno}

The surface layer with relatively low resistivity values $(<40 \mathrm{k} \Omega \mathrm{m})$ and thickness ranging between 1 and $5 \mathrm{~m}$ can be interpreted as the active layer of the rock glacier, as evidenced by the $S_{0}$ and $S_{3}$ stratigraphies (Fig. 10a and b). The high values can be referred to the open work fabric of the deposit and to its grain size (with blocks that locally can exceed $1 \mathrm{~m}$ of diameter). Beneath this surface layer, the mass of high resistivity $(>1 \mathrm{M} \Omega \mathrm{m})$ - identified both on FS1 and FS2 - can be associated to the massive ice bodies detected in the cores of $S_{0}$ and $S_{3}$ (Fig. 10a and b). Only the material extracted within the $S_{0}$ borehole allowed crystallographic, chemical and isotopic analyses on the massive ice found between 2 and $7 \mathrm{~m}$ of depth (see also Fig. 11a). The results clearly indicate a sedimentary origin of this ice (i.e. "glacier ice") (Guglielmin et al., 2004; Stenni et al., 2007).

$\mathrm{S}_{0}$ and $\mathrm{S}_{3}$ indicate that the resistivities higher than $90-100 \mathrm{k} \Omega \mathrm{m}$ which surround the massive ice bodies can be interpreted as frozen sediment with medium to high ice content.

Moreover, the drastic fall of resistivity to values constantly lower than $10 \mathrm{k} \Omega \mathrm{m}$ detected in the upper part of FS2 $\mathrm{m}$ a.s.l. is consistent with the stratigraphy of $S_{2}$, where the metamorphic bedrock is found a few meters below the unfrozen surficial layer (Fig. 10b).

\subsubsection{Marinet}

Here again the surface layer presents resistivities relatively high $(10-30 \mathrm{k} \Omega \mathrm{m})$ and can be interpreted as the active layer considering the open work texture and the coarse grain size of the deposit. Below this layer the large body of very high resistivity (>4-6 M $\Omega \mathrm{m}$ ) in the southwester and central part of MA1 and in the lower and central part of MA2 can be interpreted as a massive ice body of sedimentary origin, analogously to the Foscagno boreholes. Under this massive ice (MA1 and MA2) and on the northeaster side of MA1 high resistivity values - but lower than those of massive ice $(<200 \mathrm{k} \Omega \mathrm{m})$ occur. These values suggest the occurrence of frozen ground highly rich in ice below the maximum depth reached by the tomographies.

\subsubsection{Schiantala}

The first 5-7 $\mathrm{m}$ of the subsurface below the SC1 are exposed on the slope of the glacial-karst depression (see also Fig. 11c). Here, a 1-2 m surficial detritical layer (with resistivity $<40 \mathrm{k} \Omega \mathrm{m}$ ) overlays a massive and foliated ice (4-5 M $\Omega \mathrm{m}$ ). Analogously to the Foscagno rock glacier, crystallographic analysis identified the sedimentary origin of this ice mass (Ribolini et al., 2007).

The lower resistivities $(600 \mathrm{k} \Omega \mathrm{m})$ that characterize the upvalley part of SC2, at the rock glacier root, could be interpreted either as the downvalley part of this sedimentary ice lens, or as a fragment of it syngenetically involved in the permafrost creep (Fig. 8 and b). 
a

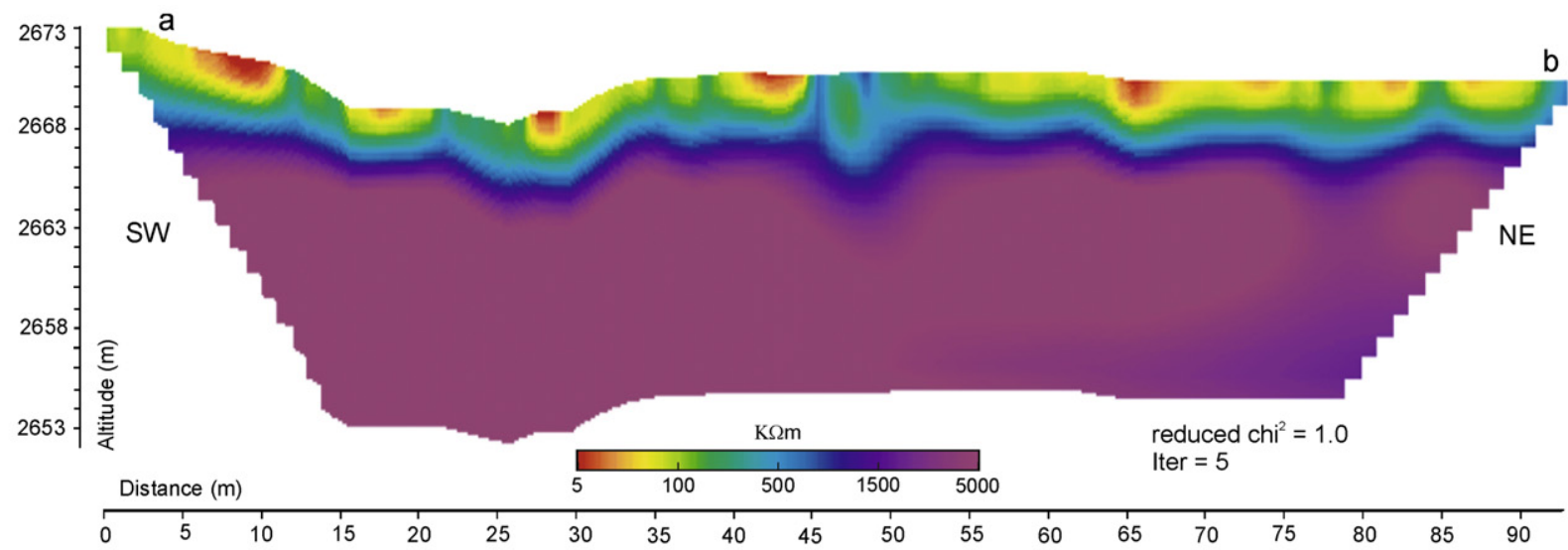

b
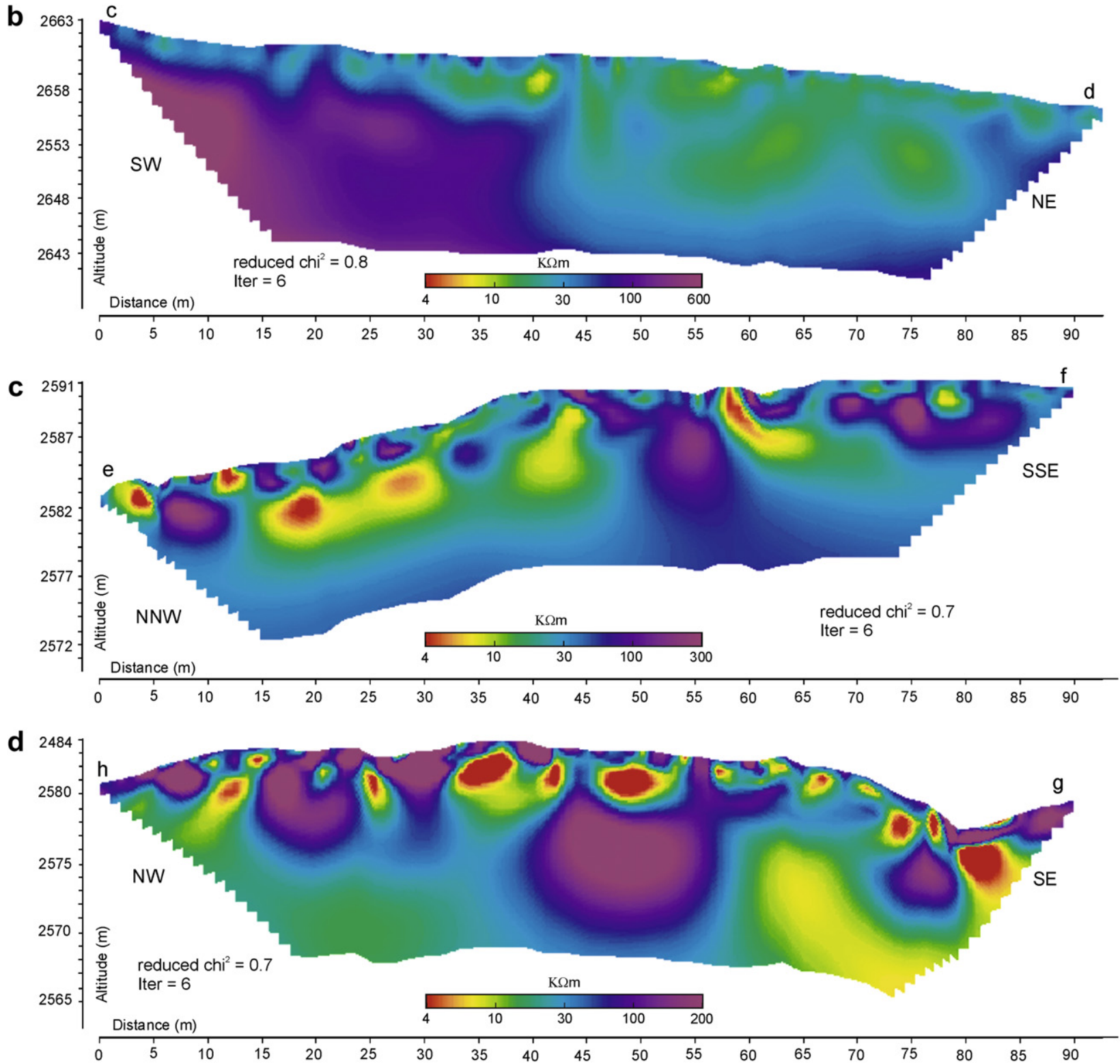

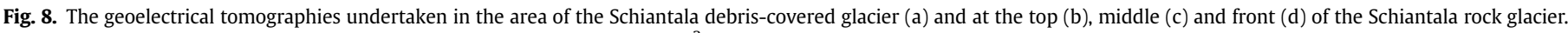

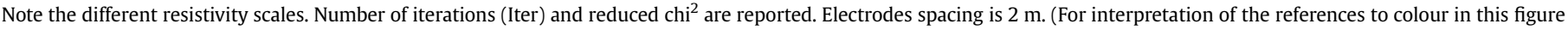
legend, the reader is referred to the web version of this article.) 

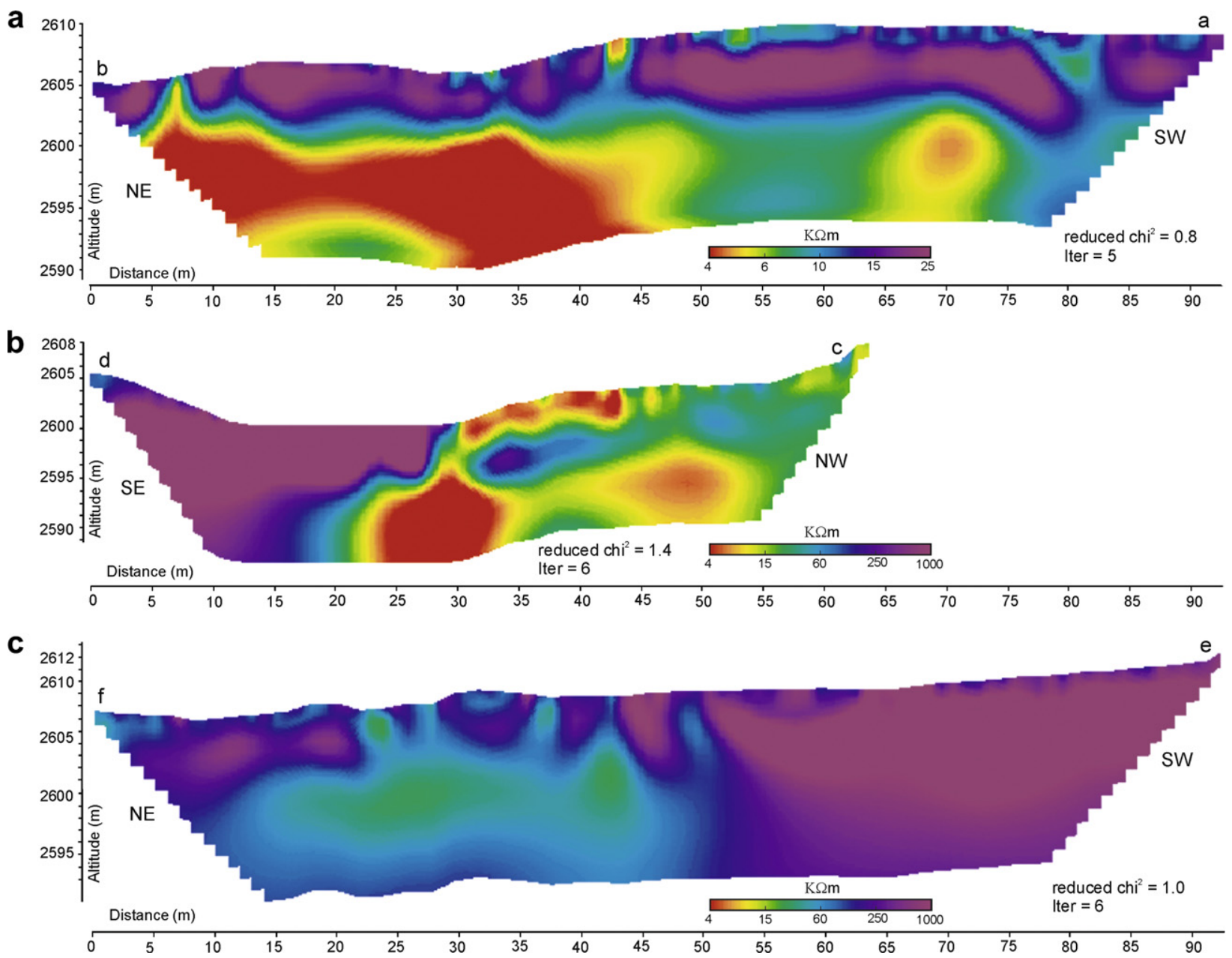

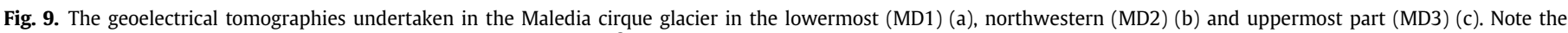

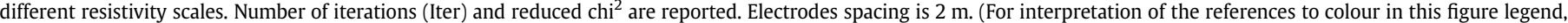
the reader is referred to the web version of this article.)

Even though these resistivities could also be interpreted as a permafrost very rich in ice, the type of deposit (very coarse and heterogeneous) and the lack of typical surface feature of permafrost creep are not in favor of this hypothesis.

Moving downward, this body terminates sharply, intruding into a layer of relatively lower resistivity $(90-100 \mathrm{k} \Omega \mathrm{m})$ that can be interpreted as permafrost with a medium ice content. The downvalley part of SC2, and those relative to SC3 undertaken in the middle of the rock glacier, indicates the presence of an ice-rock mixture in variable proportions, with local spots moderately rich in ice, but also areas slightly frozen or unfrozen.

In the frontal area, SC4 shows lenticular spots of high ice content, together with an increase in the amount of unfrozen sediments especially near the lateral sides of the rock glacier.

\subsubsection{Maledia}

MD1 shows an upper layer (0-9 m) of sediments slightly frozen or partly frozen, where a medium-low ice content $(>40 \mathrm{k} \Omega \mathrm{m})$ is limited to the sub-horizontal lens near the surface. The distribution of resistivity in this layer can be interpreted as the result of recongelation ice formation inside ablation or flow till. This upper layer stands onto a basement gently undulated and located at a depth variable between 6 and $12 \mathrm{~m}$.

MD2 shows the presence of a very shallow massive ice lens on the SE side, toward the bottom of the cirque. Frozen sediments with variable ice content and resting on unfrozen sediments and/or bedrock occur in the NW side.

A near-surface lens of massive ice is evident also in the SW part of MD3 ( $>5 \mathrm{M} \Omega \mathrm{m}$ ), gradually passing to a debris-ice mixture rich in ice beneath $8-9 \mathrm{~m}(300-400 \mathrm{k} \Omega \mathrm{m})$. In the NE side of MD3 the resistivities values are consistent with the presence of an ice-debris mixture in variable proportion $(30-500 \mathrm{k} \Omega \mathrm{m})$, but showing a decrease in ice content with depth.

Similarly to the previous sites, the shallow bodies of massive ice in MD2 and MD3 can be interpreted as masses of sedimentary ice.

\subsection{Ice distribution and glaciological evolution of the landscape}

\subsubsection{Rock glaciers}

By combining the data collected in this work with those from previous investigations in the same areas, it is possible to analyze the variation of internal ice passing from the apical to the frontal part of the studied rock glaciers (Fig. 11a-c).

The ice content along longitudinal profile of Marinet and Schiantala rock glaciers shows a trend with high value in the upper part, low in the middle and again high at the front (Evin and Fabre, 1990; Ribolini and Fabre, 2006 and this work). A similar trend has been observed elsewhere: St Anne rock glacier, Queyras, French Alps; "Grüben" rock glacier, Swiss Alps (King et al., 1987; Fabre et al., 1995; Assier et al., 1996). 


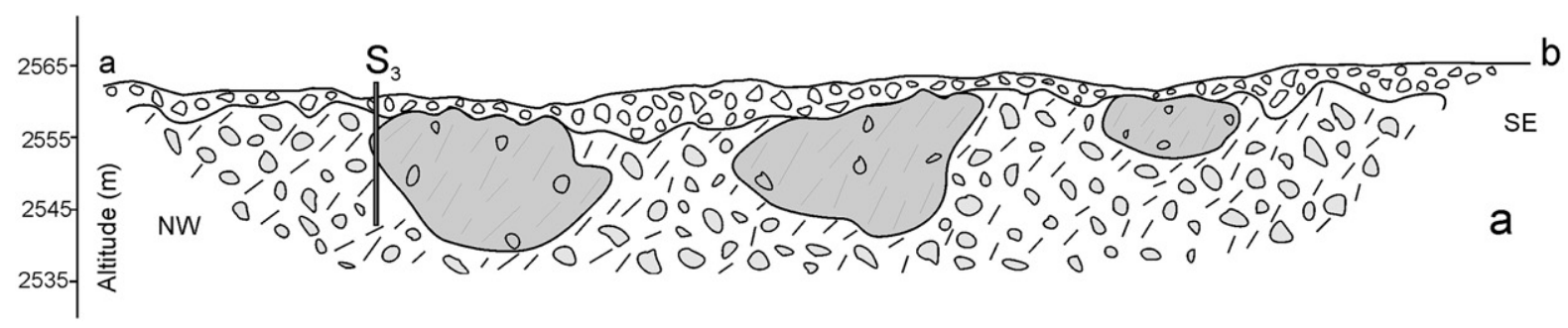

Distance $(\mathrm{m})$

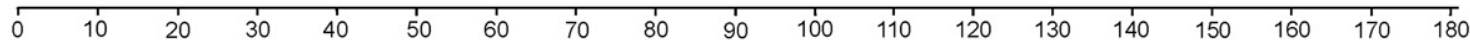

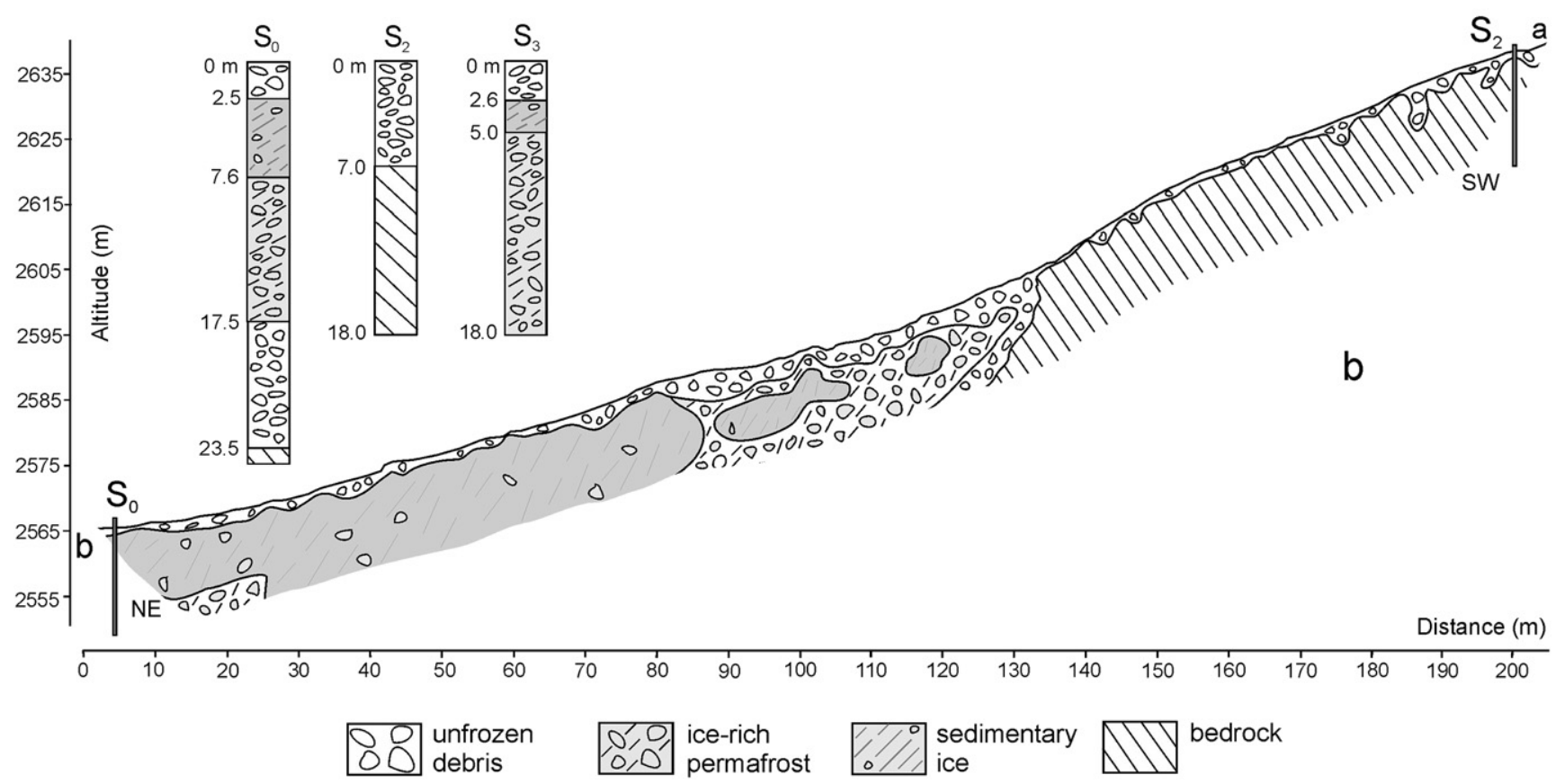

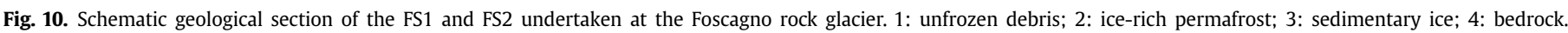
Cryological interpretation of boreholes stratigraphy is shown (original data in Stenni et al., 2007).

The Foscagno rock glacier shows a completely different distribution with a sharp disappearance of ice along the longitudinal profile on the southern side of the rock glacier at the elevation of about $2600 \mathrm{~m}$ a.s.l. This elevation corresponds to the lower extension of the AD 1931 glacier. The Foscagno rock glacier, as shown by the FS1 tomography, also present strong lateral variations, as already indicated by previous VES (Guglielmin et al., 1994).

This result is in contrast to what frequently found in other studies where the detected ice content decreases quite regularly from the root to the front of the rock glacier as in the case of the Petite Part rock glacier (Queyras region, French Alps) (Evin and Fabre, 1990; Assier et al., 1996), or at the Las Argualas rock glacier (Pyrenees, Spain) (Fabre et al., 1995), or at the Camp and North rock glaciers (Grizzly Creek, Yukon, Canada) (Evin et al., 1997).

The climatic equilibrium between permafrost and glacial conditions (Haeberli, 1983; Humlum, 1998) can change through time and a cold and snowy period can determine the advance of a glacier on top of a neighboring downvalley rock glacier. The consequent overriding of the mid-upper part of the rock glacier by a glacier tongue can cause I) the degradation of the underlying permafrost ice through ground thermal regime modification and/or meltwater circulation, II) the embedding of fragments of sedimentary ice in a permafrost syngenetically aggrading.
Case I is represented by the Foscagno rock glacier where it is known that a glacier advance during the LIA overrode the root of the rock glacier and rested on it until 1932 (Guglielmin et al., 2001; Guglielmin et al., 2004). The thermal effect of this LIA glacier advance is testified by the daily thermal profiles recorded in the $S_{2}$ and $S_{0}$ boreholes (Fig. 12). The former, located at higher elevation but in the area glaciated until 1932, does not show any permafrost as suggested by the isothermal profile around $0.3^{\circ} \mathrm{C}$. The latter $\left(\mathrm{S}_{0}\right)$, close to the rock glacier front, shows an articulated profile with the upper part of the massive ice glacial body at the melting point temperature.

The limit of unfrozen material revealed by tomography FS2 is coincident with the lower limit of the glacier in 1932 AD. Analogously, the decrease of resistivity in middle of Marinet rock glacier (Evin and Fabre, 1990) can be related to the same effect of permafrost degradation induced by the Marinet Glacier West, extended in 1924 to cover the mid-upper part of the rock glacier (Mougin, 1927).

The Schiantala rock glacier figures out the case II. Here, the interaction between glacier and rock glacier is ongoing or recent. The sedimentary ice at the topmost part (SC2) seems to be the terminus of the current debris-covered Schiantala glacier intruding the rock glacier root or, alternatively, a fragment of the LIA Schiantala glacier now embedded in the permafrost creep (Ribolini et al., 2007). 
a

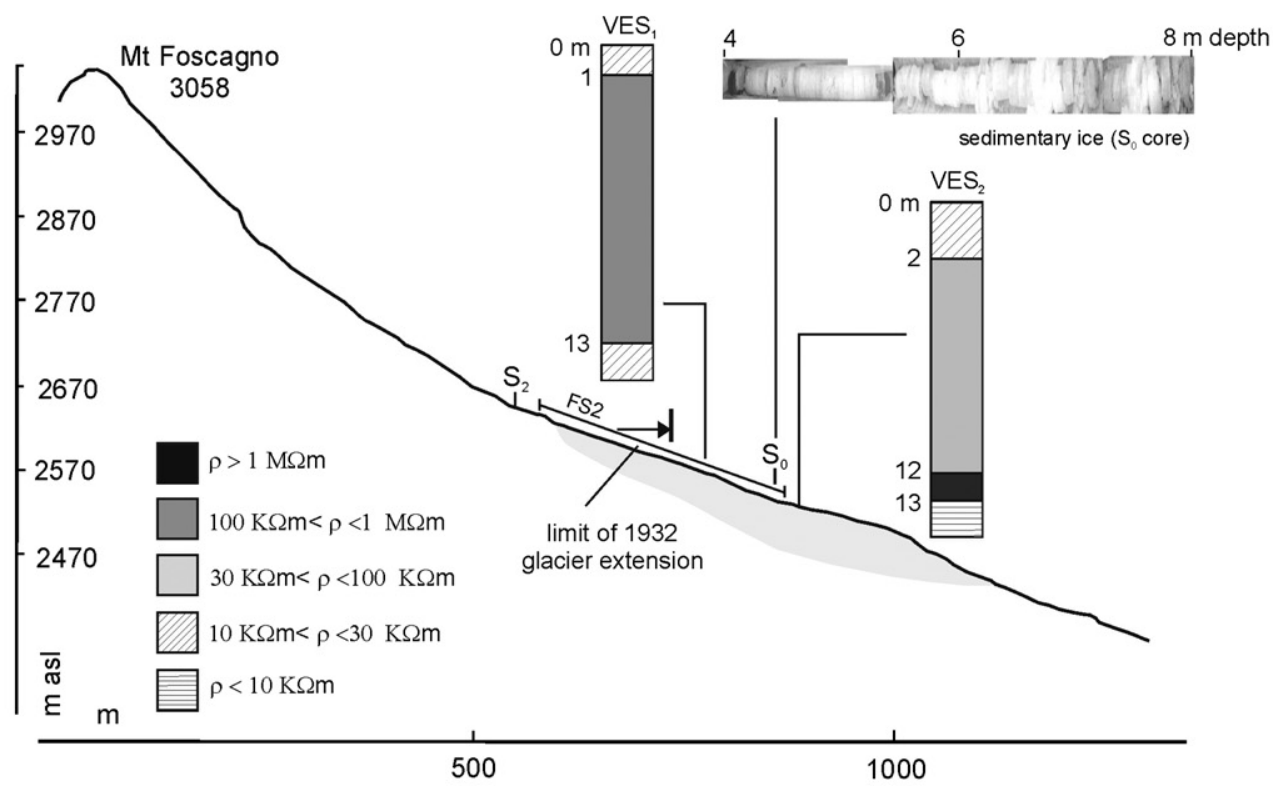

b
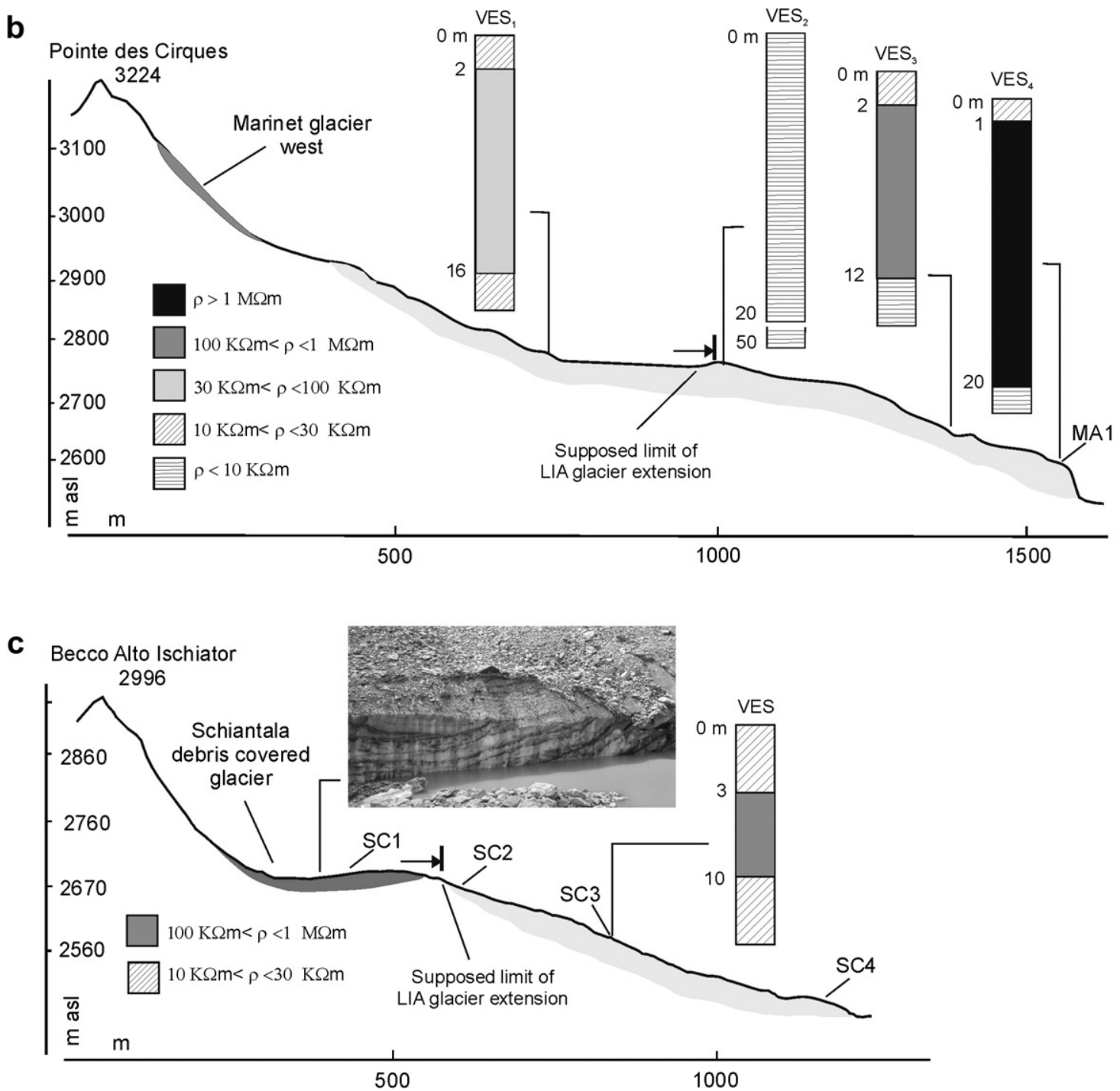

Fig. 11. Composite cartoon reporting the main previous geoelectrical and geomorphological data by Foscagno (a), Marinet (b) and Schiantala (c) rock glaciers. See Figs. 2-4 for location of the used Vertical Electrical Sounding (VES). Data sources: Assier (1996); Evin and Fabre (1990); Guglielmin (1997); Ribolini and Fabre (2006); Ribolini et al. (2007); Stenni et al. (2007). 


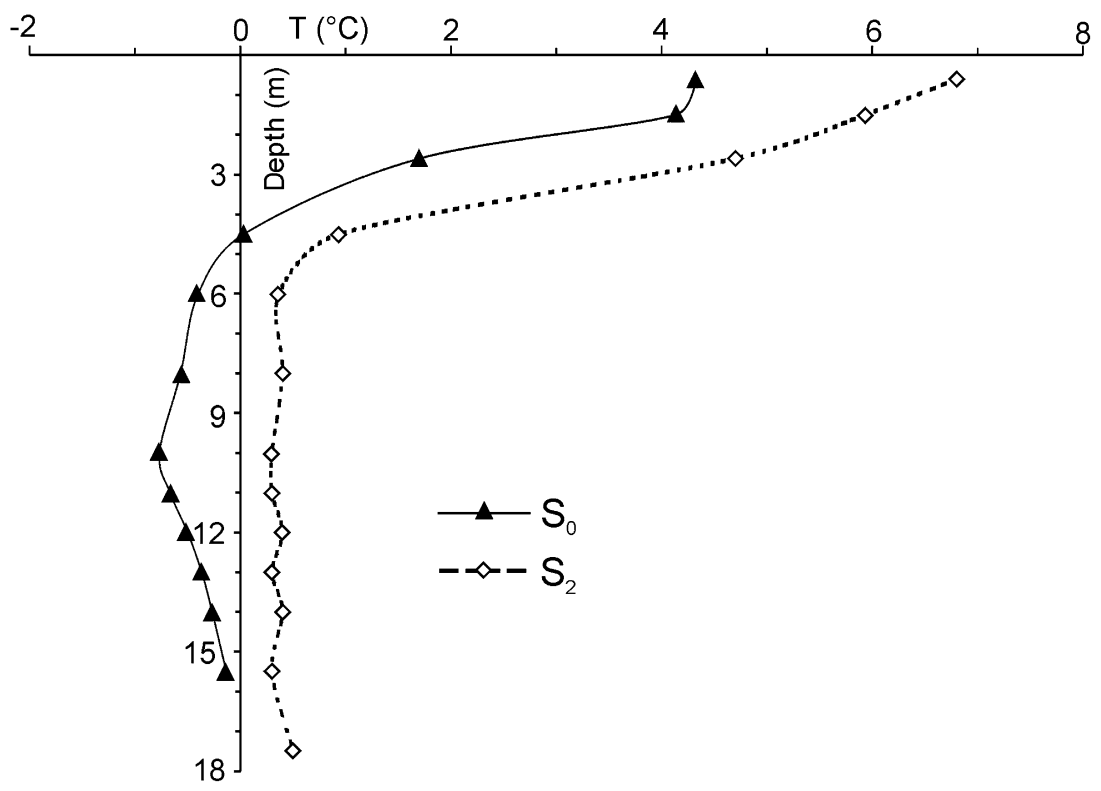

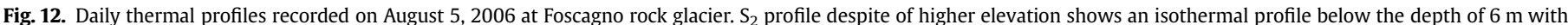
a temperature approximately constant around $+0.3^{\circ} \mathrm{C}$, whereas the profile of $\mathrm{S}_{0}$ shows an articulated profile with the upper part (less than $1 \mathrm{~m}$ ) at melting temperature.

It is more difficult to assess whether or not the massive ice at the front of the Marinet rock glacier could be a fragment of a previous glacier, because no outcrops or borehole evidences support this hypothesis. However, the great thickness (more than 20 m detected by a VES reported in Evin and Fabre, 1990) and the thin active layer ( $2 \mathrm{~m}$ ) of glacier suggests a sedimentary origin of the massive ice, avoiding a supra-permafrost lens of high resistivity ice formed in an active layer thicken in a compressive setting.

\subsubsection{Recently deglaciated areas}

In most of the bottom of the Schiantala cirque, glacigenic and slope debris show evidence of an intense settlement extended to an area of about $16,500 \mathrm{~m}^{2}$, suggesting a wider extension of the nearsurface sedimentary ice detected by tomography SC1. The absence of a thick active layer and a debris supply (litic skeleton) in the ice itself enhanced the thermal destabilization of the massive ice body. The ongoing acceleration of climatic warming forced the melting processes and led to the formation of the glacial-karst lake that appeared in the 1970s (Evin, 1993). The area occupied by the current debris-covered glacier was occupied by the Schiantala glacier during the LIA (Ribolini et al., 2007), and was already totally covered in debris at the beginning of 20th century (Camoletto, 1931).

The sedimentary ice masses that are present in the recently deglaciated area of the Maledia cirque slopes can be related to fragments of buried dead ice detached from the main body, or alternatively as the debris covered termination of the Maledia glacier itself, still visible on the surface $\sim 40 \mathrm{~m}$ above the surveyed area. Both hypotheses are consistent with the fact that the sectors prospected with the tomographies were occupied by the Maledia glacier at least up to the 1931 (Federici and Pappalardo, 1995).

The similar evolution of Schiantala and Maledia glaciers highlights the role of a progressive and irreversible debris coverage in their exhausting process. The Schiantala situation could represent what the Maledia glacier is rapidly becoming. The Schiantala glacier was already totally covered by debris at the beginning of 20th century, while the Maledia glacier is still visible and extended to most of the cirque floor in the 1930s.

Moreover, the sedimentary ice masses found in the till abandoned by the Maledia glacier are locally associated to medium- high resistive sediments, consistent with permafrost occurrence. This fact suggests that the environmental condition established during the last 70 years determined the deglaciation of most of the area and favored the onset of permafrost formation with development of recongelation ice into the slopes abandoned by the glacier. If we take into consideration the different temporal scale of glacier and permafrost response to climatic variations, the internal structure of the glacigenic sediments marginal to the Maledia glacier front mirrors the shift from glacial to periglacial condition in which frost action dominates.

\section{Conclusion}

The results of this work confirm that a spectrum of different types of ice coexists in the same detrical body in high alpine slopes. The resistivities detected in the studied rock glacier indicate an internal structure characterized by highly variable ice content, as well as massive ice lenses of sedimentary origin ("glacier ice") both in apical and frontal parts.

The electrical resistivity distribution along the flow direction of the examined rock glaciers, if mechanical reasons can be excluded, suggests interactions with a glacier snout. A glacial overrode disrupting the permafrost can be claimed to explain the scarcity of frozen debris/ice in the upper or middle part of rock glaciers, i.e. Foscagno and Marinet rock glaciers. On the other hand, ice transfer from a glacial snout to sectors of rock glacier can cause the embedding of fragments of sedimentary ice in a syngenetically permafrost creeping, eventually transported downvalley by the flow, i.e. fronts of Foscagno and Marinet rock glaciers, root of Schiantala rock glacier.

These results confirm that the internal structure of rock glaciers have proved to represent an potential archive that stores the different climate-related episodes occurred in an area, such as the shifting from glacial to periglacial conditions and vice-versa.

Moreover, in areas recently deglaciated or involved in an ongoing process of glacier exhausting, an upward increase in resistivity is generally observed, with near-surface massive ice lenses only covered by a thin debris layer and associated to unfrozen/slightly frozen sediments. The buried lens of sedimentary 
ice still occupying the bottom and the slopes of the glacial cirque can be the debris-covered termination of a glacier still visible upward, or fragments of it detached by the main body (i.e. Maledia glacier). Alternatively, the massive sedimentary ice detected by the subsurface resistivities can indicate that beneath the debris a glacier is still existing, even when considered already gone for a long time (i.e. Schiantala glacier). Even though geophysical prospection extended to wider areas are needed, these results highlights that the debris coverage plays an important role in the mechanism of extinction of the glaciers in the examined area.

Furthermore, the reconstructed electrical stratigraphy suggests that the cold non-glacial environment established during the deglaciation allowed the onset of frozen sediments formation surrounding the masses of sedimentary ice. Hence, similarly to rock glaciers, the internal structure of deglaciated areas can record the effects of the shifting from glacial to criotic condition.

\section{Acknowledgments}

This research was supported by COFIN 2005 "Increasing rate of Climate Change impacts on high mountain areas: cryosphere shrinkage and environmental effects" and "Short Mobility" program by Italian CNR. We thank D. Bastoncelli, M. Bini, M. Capitani, N. Casarosa, D. Giuntini (Geomorph Lab, University of Pisa) for assistance in the field. We thank A. Bianchi, P. Ciuffi (SO.GE.T, www. sogetsnc.eu, Lucca), L. D'Onofrio (University of Pisa) and A. Ciucci (Geostudi Astier Srl, Livorno) for assistance in the lab. Geophysical data acquisition in the Maledia area and review of the paper by M. Pappalardo (University of Pisa) were very helpful in developing this work.

\section{References}

Assier, A., 1996. Glaciers et glaciers rocheux de l'Ubaye. Sabença de la Valeia, Barcelonnette. Bernard Vial, pp. 32.

Assier, A., Evin, M., Fabre, D., 1996. Prospection électrique sur les glaciers rocheux du cirque de Sainte-Anne (Queyras, Alpes du Sud, France). Permafrost and Periglacial Processes 7, 53-67.

Berger, J., Krainer, K., Mostler, W., 2004. Dynamics of an active rock glacier (Ötzal Alps, Austria). Quaternary Research 62, 233-242.

Camoletto, C.F. 1931. Le variazioni periodiche dei ghiacciai delle Alpi Marittime. Bollettino del Comitato Glaciologico Italiano 1 (11), 189-212.

Calderoni, G., Guglielmin, M., Tellini, C., 1998. Radiocarbon dating and postglacial evolution, Upper Valtellina and Livignese area (Sondrio, Central Italian Alps). Permafrost and Periglacial Processes 9, 275-284.

Clark, D.H., Steig, E.J., Potter, N.J., Fitzpatrick, J., Updike, A.B., Clark, G.M., 1996. Old ice in rock glaciers may provide long-term climate records. EOS, Transactions. American Geophysical Union 77, 217-222.

Davis, J.C., 1990. Statistics and Data Analysis in Geology. John Wiley \& Sons, New York, $656 \mathrm{pp}$

Etzelmüller, B., Hagen, J.O., 2005. Glacier-permafrost interaction in arctic and alpine mountain environments with examples from southern Norway and Svalbard. In: Harris, C., Murton, J.B. (Eds.), Cryospheric Systems: Glaciers and Permafrost. Geological Society, London, Special Publications, vol. 242, pp. 11-27.

Everest, J., Bradwell, T., 2003. Buried glacier ice in southern Iceland and its wider significance. Geomorphology 52, 347-358.

Evin, M., 1993. Glacier et glacier rocheux dans les vallons de Mongioie et de Schiantala. Une nouvelle interprétation. Zeitschrift für Gletscherkunde und Glazialgeologie 27/28, 1-10.

Evin, M., de Beaulieu, J.L., 1985. Nouvelles données sur l'age de la mise en place et les phases du activité du glacier rocheux de Marinet I (Haute-Ubaye, Alpes du Sud françaises). Méditerranée 4, 21-30.

Evin, M., Fabre, D., 1990. The distribution of permafrost in rock glaciers of Southern Alps (France). Geomorphology 3, 57-71.

Evin, M., Fabre, D., Johnson, P.G., 1997. Electrical resistivity measurements on the rock glacier of Grizzly Creek, St Ellias Mountains, Yukon. Permafrost and Periglacial Processes 8, 179-189.

Fabre, D., Garcia, F., Evin, M., Martinez, R., Serrano, E., Assier, A., et al., 1995 Structure interne du glacier rocheux actif de las Argualas (Pyrenes aragonaises, Espagne). La Houille Blanche 5-6, 144-147.

Federici, P.R., Pappalardo, M., 1995. L'evoluzione recente dei ghiacciai delle Alpi Marittime. Geografia Fisica e Dinamica Quaternaria 18, 257-269.

Guglielmin, M., 1997. Il permafrost Alpino. Concetti, morfologia e metodi di individuazione (con tre indagini esemplificative in Alta Valtellina). In: Quaderni di Geodinamica Alpina e Quaternaria, vol. 5. CNR, 117 pp.
Guglielmin, M., Cannone, N., Dramis, F., 2001. Permafrost-glacial evolution during the Holocene in the Italian Central Alps. Permafrost and Periglacial Processes $12,111-124$

Guglielmin, M., Lozej, A., Tellini, C., 1994. Permafrost distribution and rock glaciers in the Livigno Area, Northern Italy. Permafrost and Periglacial Processes 5, 1-12.

Guglielmin, M., Camuso, M., Polesello, S., Valsecchi, S., 2004. An old relict glacier body preserved in permafrost environment: the Foscagno rock glacier (upper Valtellina, Italian Central Alps). Arctic, Antarctic and Alpine Research 36, 108-116.

Haeberli, W., 1983. Permafrost-glacier relationship in the Swiss Alps - today and in the past. In: Proceeding of the 4th International Conference on Permafrost, Fairbank, Alaska, pp. 415-420.

Haeberli, W., 2005. Investigating glacier/permafrost-relations in high areas: historical background, selected examples and research needs. In: Harris, C., Murton, J.B. (Eds.), Cryospheric Systems: Glaciers and Permafrost. Geological Society, London, Special Publications, vol. 242, pp. 29-37.

Haeberli, W., Vonder Mühll, D., 1996. On the characteristics and possible origins of ice in rock glacier permafrost. Zeitschrift für Geomorphologie NF Supplementband 104, 43-57.

Haeberli, W., Hallet, B., Arenson, L., Elconin, R., Humlum, O., Kääb, A., et al., 2006. Permafrost creep and rock glacier dynamics. Permafrost and Periglacial Processes 17, 189-214.

Harris, C., Murton, J.B., 2005. Interactions between glaciers and permafrost: an introduction. In: Harris, C., Murton, J.B. (Eds.), Cryospheric Systems: Glaciers and Permafrost. Geological Society, London, Special Publications, vol. 242, pp. 1-9.

Hauck, C., 2001. Geophysical methods for detecting permafrost in high mountains. Versuchsanstalt für Wasserbau, Hydrologie und Glaziologie, ETH, Mitteilungen $171,204$.

Hauck, C., Vonder Mühll, D., Maurer, H., 2003. Using DC resistivity tomography to detect and characterize mountain permafrost. Geophysical prospecting 51, 273-284.

Humlum, O., 1998. The climatic significance of rock glaciers. Permafrost and Periglacial Processes 9, 375-395.

Kääb, A., Kneisel, C., 2006. Permafrost creep within a recently deglaciated glacier forefield: Muragl, Swiss Alps. Permafrost and Periglacial Processes 17, 79-85.

King, L., Fisch, W., Haeberli, W., Wächter, H.P., 1987. Comparison on resistivity and radio-echo soundings on rock glacier permafrost. Zeitschrift für Gletscherkunde und Glazialgeologie 23, 77-97.

Kneisel, C., 2003. Permafrost in recently deglaciated glacier forefield - measurements and observations in the Eastern Swiss Alps and Northern Sweden. Zeitschrift für Geomorphologie 47, 289-305.

Kneisel, C., 2004. New insights into mountain permafrost occurrence and characteristics in glacier forefields at high altitude through the application of 2D resistivity imaging. Permafrost and Periglacial Processes 15, 221-227.

Kneisel, C., Kääb, A., 2007. Mountain permafrost dynamics within a recently exposed glacier forefield inferred by a combined geomorphological, geophysical and a photogrammetrical approach. Earth Surface Processes and Landform 32 1797-1810.

LaBrecque, D.J., Miletto, M., Daily, W.D., Ramirez, A.L., Owen, E., 1996. The effects of noise on occam's inversion of resistivity tomography data. Geophysics 61, 538-548.

Lugon, R., Delaloye, R., Serrano, E., Reynard, E., Lambiel, C., Gonzalez-Trueba, J.J., 2004. Permafrost and little ice age glacier relationships, Posets Massif, Central Pyrenees, Spain. Permafrost and Periglacial Processes 15, 207-220.

Maurer, H., Hauck, C., 2007. Geophysical imaging of alpine rock glaciers. Journal of Glaciology 53 (180), 110-120.

Morelli, G., LaBrecque, D.J., 1996. Advances in ERT inverse modelling. European Journal of Environmental and Engineering Geophysics 1, 171-186.

Moorman, B.J., Michel, F.A., 2000. The burial of ice in the proglacial environment on Bylot Island, Arctic Canada. Permafrost and Periglacial Processes 11, 161-175.

Mougin, P., 1927. Les glaciers de marinet. Etudes glaciologiques. Ministère de l'agriculture. Direction Générale des Eaux et Forêts 6, 150-156.

Pappalardo, M., 1999. Remarks upon the present-day condition of the glaciers in the Italian Maritime Alps. Geografia Fisica e Dinamica Quaternaria 22, 79-82.

Reynard, E., Lambiel, C., Delaloye, R., Devaud, G., Baron, L., Chapellier, D., et al., 2003. Glacier/permafrost relationships in forefields of small glaciers (Swiss Alps). In: Proceedings 8th International Conference on Permafrost, Zurich, Switzerland, vol. 2. Balkema, pp. 947-952.

Ribolini, A., 2001. Active and fossil rock glaciers in the Argentera Massif (Maritime Alps): surface ground temperatures and paleoclimatic significance. Zeitschrift für Gletscherkunde und Glazialgeologie 37, 125-140.

Ribolini, A., Fabre, D., 2006. Permafrost existence in the rock glaciers of the Argentera Massif (Maritime Alps, Italy). Permafrost and Periglacial Processes 17, 49-63.

Ribolini, A., Chelli, A., Guglielmin, M., Pappalardo, M., 2007. Relationships between glacier and rock glacier in the Maritime Alps, Schiantala Valley, Italy. Quaternary Research 68, 353-363.

Stenni, B., Genoni, L., Flora, O., Guglielmin, M., 2007. An oxygen isotope record from the foscagno rock-glacier ice core, Upper Valtellina, Italian Central Alps. The Holocene 17 (7), 1033-1039.

Telford, W.M., Geldart, L.P., Sheriff, R.E., 1990. Applied Geophysics. Cambridge University Press, New York, 770 pp.

Whalley, W.B., Palmer, C.F., 1998. A glacial interpretation for the origin and formation of the Marinet rock glacier, Alpes Maritimes, France. Geografiska Annaler 80, 221-236. 